\title{
Senescent stem-galls in trees of Eremanthus erythropappus as a resource for arboreal ants
}

\author{
Maria Fernanda B. de Almeida ${ }^{1,2}$, Leonardo Rodrigues dos $\operatorname{Santos}^{1} \&$ Marco Antonio A. Carneiro $^{1}$
}

\author{
${ }^{1}$ Lab. Entomologia Ecológica do Instituto de Ciências Biológicas e Exatas, Universidade Federal de Ouro Preto, Campus Morro do Cruzeiro, \\ 35400-000 Ouro Preto-MG, Brasil. \\ ${ }^{2}$ Corresponding author: febritobio@gmail.com
}

\begin{abstract}
Senescent stem-galls in trees of Eremanthus erythropappus as a resource for arboreal ants. Members of the dipteran families Tephritidae and Cecidomyiidae are inducers of stem-galls in Eremanthus erythropappus (DC.) MacLeish (Asteraceae), a tree common in the state of Minas Gerais, Brazil. When senescent, these galls become available to other organisms, such as ants. The present study describes a community of ants having benefitted from this process of ecosystem-engineering. The colonies in question inhabit the senescent stem-galls of trees of E. erythropappus and were examined in view of answering the following questions: i) whether the presence of stem-galls had any bearing on the richness, composition, or size of the ant colonies therein; and ii) whether the ants displayed any preferences regarding the shape and/or size of the galls. The study was conducted in populations of E. erythropappus trees near the city of Ouro Preto, MG. A total of 227 galls were collected, $14 \%$ of which were occupied by ants, belonging to eight different species. Half of the species occupied galls of both morphotypes (fusiform and globular), although we observed a marked preference for larger, globular shapes. Overall, our results showed the galls to be an effective and abundant resource, helping to maintain the diversity of the ants in the canopy. We also observed the occurrence of outstations and polydomic nests, although an in-depth examination of the influence of galls on this type of structuring has not been investigated
\end{abstract}

KEYWORDS. Herbivores; Insecta; interaction; nesting.

Interactions among living organisms involve both biotic and abiotic factors, having direct and indirect effects on the distribution and abundance of organisms. One such factor is the creation of novel structures or cavities by some species which have developed the ability to physically manipulate their environments. These structural changes impact the entire habitat - sometimes creating entirely new habitats - and have collateral effects which can create new opportunities, resources or favorable conditions for other species, and for this reason, these organisms have been dubbed ecosystem engineers (Jones et al. 1994). Since then they have been widely studied, although the more specific phenomena of insect-herbivores and their effects on the formation of cavities in plants (especially as they occur in the neotropical savanna, or cerrado) is a subject that has yet to be fully explored (Del-Claro \& Torezan-Silingardi 2009).

Herbivore insects, which comprise almost $50 \%$ of all known insect species and a very large part of the biomass of tropical ecosystems (Schoonhoven et al. 2005), often serve as ecosystem engineers within their habitats. Gall-inducing insects in particular tend to play this role. Essentially, these insects manipulate their host plants by inducing galls which are then used by themselves, or subsequently by others, as resources (Craig et al. 1991; Andrade et al. 1995; Sanver \& Hawkins 2000). Galls, cecidia or tumors are plant tissue or organs which have formed as a result of hyperplasia (an increase in the number of cells) and/or hypertrophy (an increase in the size of the cells). These changes are induced by either parasite organisms or pathogens (Dreger-Jauffret \& Shorthouse 1992). Galls are conspicuous structures that persist in the plant and, even after having been abandoned by the inductor (that is, after having become senescent), can be occupied by new species, in particular by ants (Fernandes et al. 1988; Araújo et al. 1995; Santos et al. 2012). The galls can be colonized or merely occupied, can serve as a refuge or as foraging grounds.

In the environment of the Brazilian cerrado, the high concentration of arboreal ants can be explained by the diversity of food sources available within the vegetation, such as extrafloral nectar and insect honeydew (Oliveira \& Freitas 2004). Furthermore, the presence of galleries and stem-galls within the twigs (created by borer and gall inducing insects) are an excellent advantage and help greatly in the construction of nests by arboreal ants (Fernandes et al. 1988; Araújo et al. 1995; Oliveira \& Freitas 2004; Schoereder et al. 2010). As in the cerrado, the high diversity of galls in other plant formations such as the Atlantic forest (Coelho et al. 2013; Carneiro et al. 2014) and dry forests (Coelho et al. 2013) suggest that these galls can be widely used by ants in these environments. Therefore, the pre-formed cavities left behind by ecosystem engineers, such as galls, can act as an important resource which optimizes the efforts and the potential of local ant colonies, thus affecting the composition, richness and abundance of their population. 
The present study examines different colonies of ants having occupied the abandoned or senescent stem-galls of "candeia" trees, Eremanthus erythropappus (DC.) MacLeish (Asteraceae). It aims to determine whether the presence of stem-galls, as well as their particular size and shape, have any bearing on the richness, composition or size of the colonies living in these trees. To this end, the following questions were asked: i) Does the presence of senescent galls increases the richness and composition of arboreal ant colonies? ii) When selecting galls for occupation and/or nesting, do the ants display any preference with respect to shape and/or size?

\section{MATERIAL AND METHODS}

Study Area. The study was conducted near the city of Ouro Preto (in Minas Gerais, Brazil) at four different locations: namely, in Itacolomi State Park (PEI), at Ribeiro Mountain, Brígida Mountain and in the area beside the MG-356 highway near the entrance to the city of Ouro Preto. The PEI $\left(20^{\circ} 22^{\prime} 30^{\prime \prime} \mathrm{S}, 43^{\circ} 32^{\prime} 30^{\prime \prime} \mathrm{W}\right)$ spans approximately 7,000 ha and is composed mostly of low mountain rainforests, riparian vegetation, and quartzitic and ferruginous fields (Araújo et al.

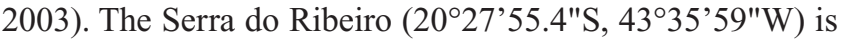
composed of rocky formations, quartzitic soil and very similar rock field vegetation (Borges et al. 2011). The Brígida Mountains $\left(20^{\circ} 21^{\prime} 47^{\prime \prime S}, 43^{\circ} 30^{\prime} 10^{\prime \prime} \mathrm{W}\right)$, which are part of the State Environmental Protection Area (APA) known as the Cachoeira das Andorinhas, are located in the vicinity of Ouro Preto, and are mostly covered by ferruginous field vegetation (known as canga) with three different phytophysionomies: herbaceous and shrubby vegetation, an area of denser vegetation including trees, and finally a seasonal forest of semi-deciduous trees. The location beside the MG-356 highway $\left(20^{\circ} 22^{\prime} 27^{\prime \prime} \mathrm{S}, 43^{\circ} 32^{\prime} 22^{\prime \prime} \mathrm{W}\right)$ is comprised of fire-damaged mesophilic vegetation currently undergoing rehabilitation. It contains mostly E. erythropappus (Pedralli et al. 1997, 2000).

Sampling. Samples were taken from four different populations of the host plant (E. erythropappus trees represented by fragments found in the areas described above). Eremanthus erythropappus (see Fig. 1A), also known as the "candeia" tree, is a pioneering arboreal species of significant economic importance (Pedralli et al. 2000).

This species is commonly found in the mountain regions of Minas Gerais, especially around the city of Ouro Preto, and is economically important due to the quality of its timber, whose durability and high energetic content make it a valuable commodity. It is also a source of the essential oil $\alpha$-bisabolol, which has been shown to have anti-inflammatory, antibacterial and antimycotic properties, and is often harvested for dermatological use (Pedralli et al. 2000). So far, scientists have identified seven different morphotypes of insect-induced leaf- and stem-galls occurring in E. erythropappus trees (Maia \& Fernandes 2004; Carneiro et al. 2009).

In the areas from which our samples were collected, $E$. erythropappus occurs mostly in monodominant formations, in disturbed environments of quartzitic fields with second- ary vegetation, along roads and access ways. The samples were taken at two periods, in March 2011 and again in March 2012 , since this is the time of year when the greatest number of galls is present. In each of the four populations, 25 specimens were chosen and labeled at random. The chosen trees measured approximately three meters in height, in order to facilitate access to the canopy. For each tree, all visible stemgalls were collected and immediately sealed (separately) in plastic bags. The stem-galls had been induced by insect species as yet unidentified but belonging to the families Tephritidae and Cecidomyiidae (see Figs. 1B, 1C and 1D).

Once in the laboratory, the stem-galls were measured with a digital caliper (margin of error: $0.01 \mathrm{~mm}$ ) in order to determine their smallest diameter, largest diameter, and height. These measurements were then used to calculate the spherical volume of globular galls $\left(\mathrm{V}=4 / 3 \pi \mathrm{r}^{3}\right)$ and the cylindrical volume of fusiform galls $\left(\mathrm{V}=\mathrm{r}^{2} \mathrm{~h} \pi\right)$. We also recorded the size (by number of individuals) of each colony found. The ants were identified as specifically as was possible (down to genus or species) by Dr. Rodrigo M. Feitosa, who consulted as references Kempf (1959), Longino (2003) and Nakano et al. (2013). The vouchers were subsequently deposited in the Museum of Zoology at the University of São Paulo.

In setting a median and interquatile range (see Table I), we took into consideration every colony of each species observed. With respect to median gall-occupation, we counted all specimens of all castes in the occupied galls.

Statistical Analysis. Because the data did not follow normal distribution, we used alternative methods for the analysis of two samples (Sprent \& Smeeton 2007). We used the Wilcoxon test to determine preferences of shape and size, where x-variables were occupation categories (unoccupied, occupied), and y-variables were diameter and volume of galls. Statistical analysis was conducted using the R statistical package (R Development Core Team 2012).

\section{RESULTS}

We collected a total of 227 senescent galls (132 of which were globular, and 95 of which were fusiform) from among 100 plants. Fourteen percent of the galls were occupied by ants (19 globular galls being occupied, as compared to 13 fusiform galls). The observed ants covered a total of four genera and eigth species (Table I).

In six cases, we were able to find two stem-galls on the same plant which were both inhabited by ants. Among these, two plants were found to contain the same species (one plant with two galls occupied by Myrmelachista sp., and another plant with two galls occupied by Crematogaster (Figs. 1E and 1F) complex crinosa sp.1. In the galls of the four remaining plants, we identified colonies of the following species: (1) Nesomyrmex aff. echinatinoidis Forel, 1886 + Nesomyrmex spininodis (Mayr, 1887); (2) Crematogaster complex crinosa sp.1+ Myrmelachista nodigera (Mayr, 1887); (3) Crematogaster complex crinosa sp.1 + Crematogaster goeldii (Forel, 1903) and (4) Crematogaster complex crinosa sp.1 + Crematogaster complex crinosa sp.2. 

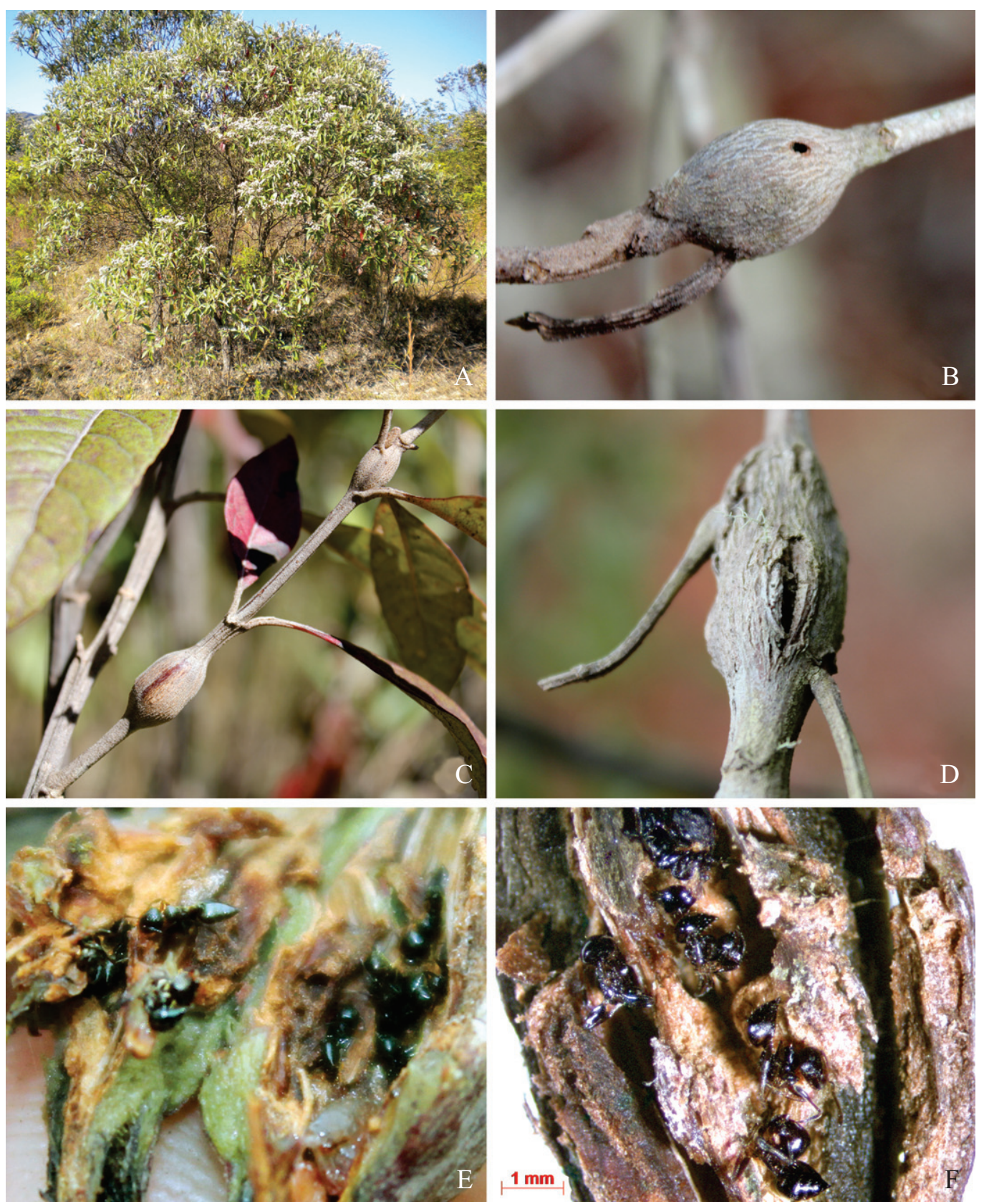

Fig. 1. The neotropical tree Eremanthus erythropappus and its galls and ants. Tree (A); senescent galls induced by species of gall midges of the families Cecidomyiidae (B and C). and Tephritidae (D); senescent, elliptical galls occupied by Crematogaster colonies (E and F).

Table I. Arboreal ant species, number and size (= median number of individuals) of colonies, as found in senescent stem-galls of Eremanthus erythropappus trees in the Ouro Preto region, Minas Gerais, Brazil.

\begin{tabular}{|c|c|c|c|c|}
\hline Taxons & $\begin{array}{l}\text { Number of } \\
\text { colonies }\end{array}$ & $\begin{array}{l}\text { Median (interquartile range) the } \\
\text { number of individuals per gall }\end{array}$ & $\begin{array}{l}\text { Median (interquartile range) the } \\
\text { number of immature forms per colony }\end{array}$ & $\begin{array}{l}\text { Median (interquartile range) the } \\
\text { number of eggs per colony }\end{array}$ \\
\hline \multicolumn{5}{|l|}{ Myrmicinae } \\
\hline Crematogaster complex crinosa sp. 1 & 11 & $10.0(1.0)$ & $0.0(0.0)$ & $8.0(0.0)$ \\
\hline Crematogaster complex crinosa sp. 2 & 1 & $17.0(17.0)$ & $3.0(3.0)$ & $7.0(7.0)$ \\
\hline Crematogaster goeldii (Forel, 1903) & 3 & $23.0(22.0)$ & $7.0(3.5)$ & $15.0(7.5)$ \\
\hline Nesomyrmex spininodis (Mayr, 1887) & 1 & $7.0(7.0)$ & $0.0(0.0)$ & $6.0(6.0)$ \\
\hline Nesomyrmex aff. echinatinodis Forel, 1886 & 3 & $9.0(6.5)$ & $3.0(2.0)$ & $5.0(3.5)$ \\
\hline Procryptocerus sp. & 2 & $1.5(1.25)$ & $0.0(0.0)$ & $0.0(0.0)$ \\
\hline \multicolumn{5}{|l|}{ Formicinae } \\
\hline Myrmelachista nodigera Mayr, 1887 & 8 & $45.50(33.0)$ & $4.0(1.5)$ & $17.0(8.75)$ \\
\hline Myrmelachista $\mathrm{sp}$. & 3 & $4.0(2.5)$ & $0.0(0.0)$ & $0.0(0.0)$ \\
\hline
\end{tabular}


Half of the ant species (4) occurred in both morphotypes of galls, except Myrmelachista sp. 1 and Nesomyrmex spininodis (Mayr, 1887), which were found exclusively in the fusiform galls (induced by Tephritidae). Likewise, Crematogaster complex crinosa sp.2 and Procryptocerus sp. were found only in the globular galls (induced by Cecidomyiidae).

Among the colonized galls, seven (22\%) contained colonies of the species Crematogaster complex crinosa sp.1, Crematogaster complex crinosa sp. 2, Myrmelachista nodigera and Nesomyrmex aff. echinatinoidis, with every caste in the colony being present.

In this study, the morphospecies Crematogaster complex crinosa sp. 1 was more numerous in terms of number of colonies. When it came to the number of individual ants per colony, Myrmelachista nodigera was the one that showed the highest median value. Regarding the presence of immature forms, the species Crematogaster goeldii showed highest median number per colony. Nevertheless, the median number of eggs per colony was highest in the species Myrmelachista nodigera (see Table I).

In general, the larger galls tended to be occupied more frequently than were the smaller ones (Volume: $\mathrm{W}=3967 ; \mathrm{p}$ $=0.003 ; \mathrm{n}=227 ;$ Fig. $2 \mathrm{~A}$. Diameter $\mathrm{W}=3917 ; \mathrm{p}=0.004 ; \mathrm{n}$ $=227$; Fig. $3 \mathrm{~A}$ ). When the fusiform and globular galls were analyzed separately, we found that the globular galls displayed the same pattern, i.e., that the ants seemed to prefer larger galls (Volume $\mathrm{W}=1487 ; \mathrm{p}=0.007, \mathrm{n}=132$; Fig. 2B. Diameter $\mathrm{W}=1487 ; \mathrm{p}=0.007 ; \mathrm{n}=132$; Fig. 3B). However, we observed no such disparity in the fusiform galls, and the ants exhibited no preference for either larger or smaller galls (Volume $\mathrm{W}=665 ; \mathrm{p}=0.15, \mathrm{n}=95$. Medium diameter $\mathrm{W}=624$; $\mathrm{p}=0.33 ; \mathrm{n}=95)$.
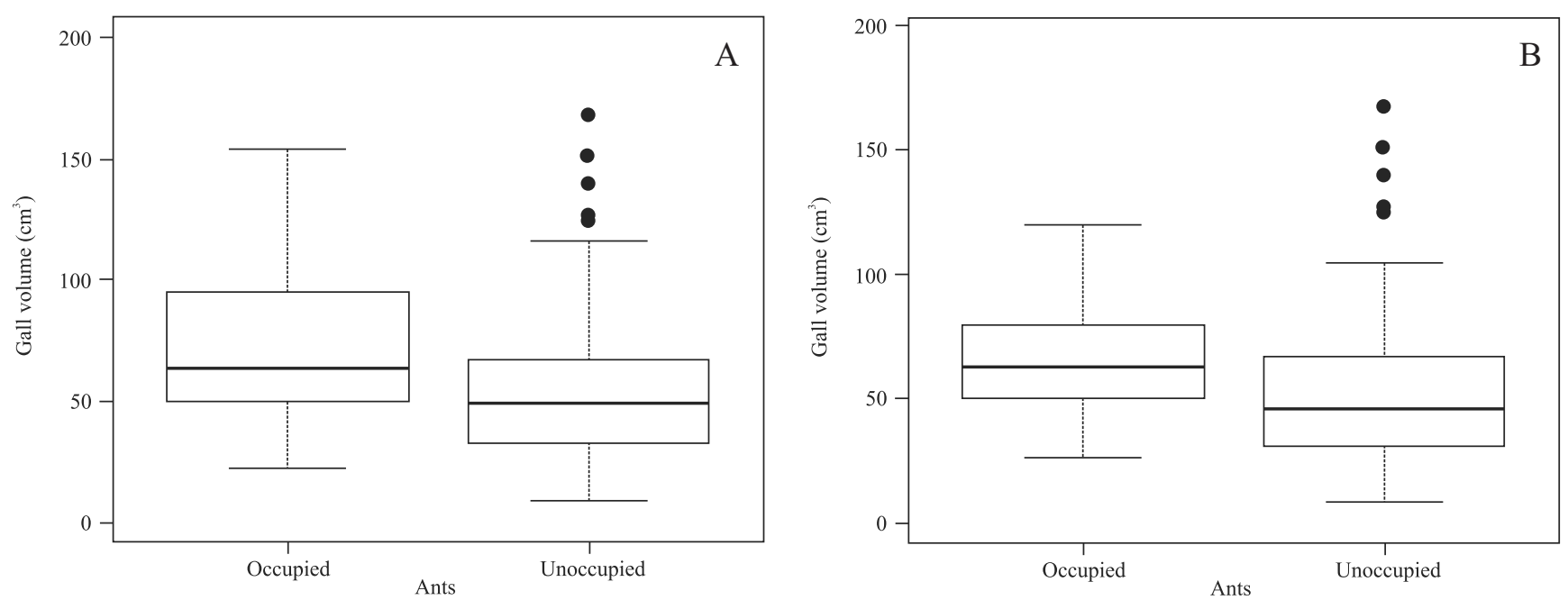

Fig. 2. Overall volume of galls occupied by ants (A); Volume of globular galls (induced by Cecidomyiidae) occupied by ants (B).
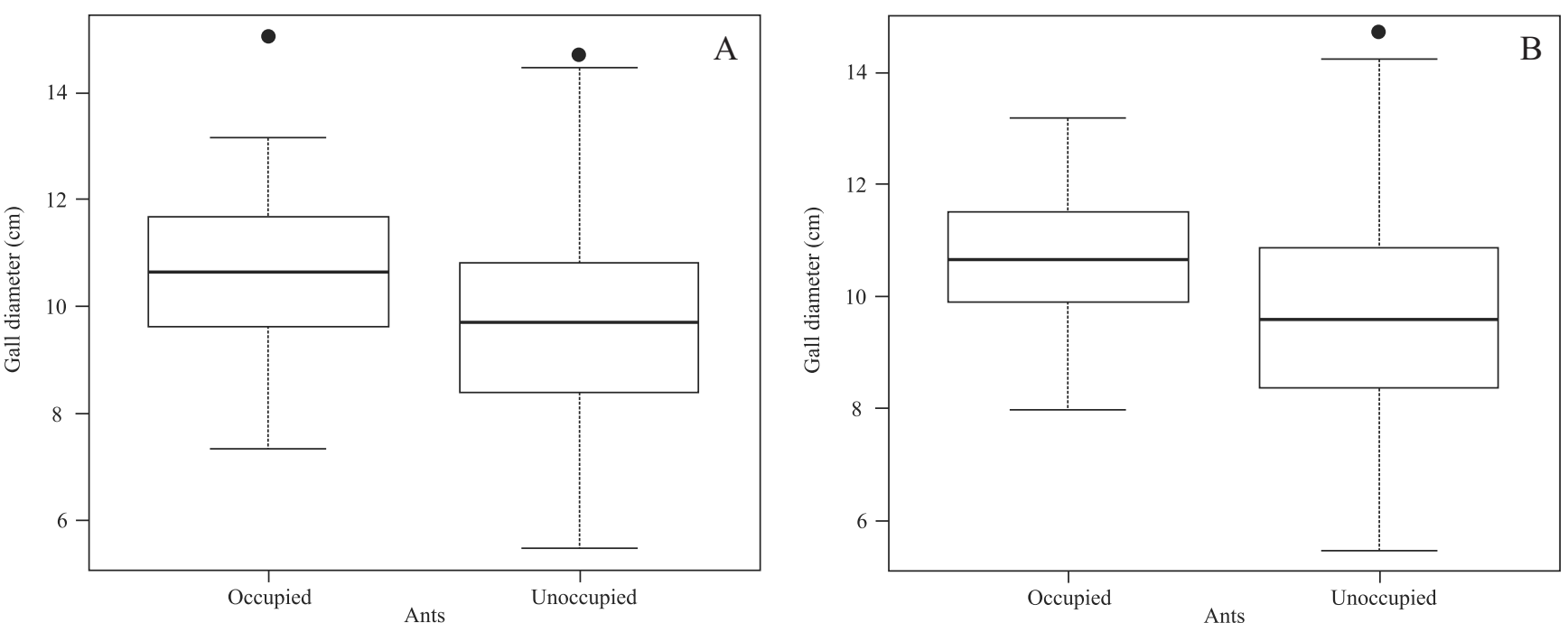

Fig. 3. Average diameter of galls occupied by ants (A) Diameter of globular galls (induced by Cecidomyiidae) occupied by ants (B). 


\section{DISCUSSION}

Previous research on the occupation of insect-built cavities in the cerrado by ants (see Table II) reported a different distribution of species than that observed here. In fact, of the eigth species observed in our research, only one (Myrmelachista nodigera) had been observed previously. In our own study, the observed rates of gall-occupation were markedly lower than those observed in previous research, with only $14 \%$ of senescent galls being occupied, by eight species of ants. By comparison, Fernandes et al. (1988) found that $45.6 \%$ of their sampled galls were inhabited by 11 species of ants. Similarly, Craig et al. (1991) and Araújo et al. (1995) reported rates as high as $48.6 \%$ (18 species of ants) and $30.5 \%$ ( 7 species of ants), respectively. The lower rate observed in our own study may be attributable to the nature of the sampling areas, which consisted of $E$. erythropappus monospecific aggregates in areas of secondary vegetation, with lower ant diversity. Cereto et al. (2011) observed a similar richness when studying populations of Actinocephalus polyanthus (Eriocaulaceae) in the Municipal Park of Dunas Lago da Conceição in Florianópolis, Santa Catarina, Brazil. They suggested that in populations of plants with aggregate distribution, the cavities of the plants may function as an ephemeral resource in large areas whose sites for nesting are scarce. Klimes et al. (2012) report that, taken generally, primary forests tend to contain roughly twice the number of ant species as do secondary forests, most likely due to the density of plants and structural complexity of their vegetation. This aspect of primary forests makes them an ideal environment for ant colonies, presenting as they do a variety of possible locations for nesting. In fact, several studies indicate a positive correlation between environmental heterogeneity (especially the richness and density of plants) and the diversity and concentration of the ants to be found therein. According to these studies, this is due to the fact that local heterogeneity provides a wider variety of resources and can therefore support a greater number of different species in many different niches (Ribas et al. 2003; Armbrecht et al. 2004).

The genera most commonly associated with herbivore cavities in cerrado vegetation are: Camponotus, Crematogaster, Myrmelachista and Pseudomyrmex (Table II), and Fernandes et al. (1988) list Cataulacus, Colobopsis, Lasius, Leptothorax as the genera of ants most likely to occupy galls. Ants of the genera Azteca, Crematogaster, Camponotus and Wasmannia are considered "truly arboreal" in that they nest in trees, whereas other genera display less specialized behavior and maintain nesting and foraging areas in many different substrates (Brown 2000; Silvestre et al. 2003; Ribas et al. 2003; Palmer et al. 2008).

Colonies founded in galls include individuals of all castes (Longino 1987; Wheeler \& Longino 1988) and in this study we observed complete colonies of Crematogaster complex crinosa sp.1, Crematogaster complex crinosa sp.2, Myrmelachista nodigera and Nesomyrmex aff. echinatinodis, accounting for roughly $22 \%$ of the colonized galls. Longino (1987) and Wheeler \& Longino (1988) report strong evidence for the fact that in some cases of gall-occupation by ants, if it never becomes necessary to find new shelter, a colony may live out its entire cycle inside the gall.

This stands in stark contrast to behaviors such as polydomic nest-construction and the addition of outstations, whose primary goal is that of expansion, that is, to increase the size of the colony in order to avoid predation and to improve the efficiency of foraging by bringing workers closer to food sources (Debout et al. 2007; Lanan et al. 2011). Polydomy is therefore considered an important factor in ecological dominance of the colony (Debout et al. 2007). Although an outstation serves the same basic purpose as polydomy (i.e., the purpose of bringing workers closer to the food source), outstations differ from domes in that they contain no immature members of the colony (Debout et al. 2007; Lanan et al. 2011). As demonstrated by Campos et al. (2008) the nesting of ants is strongly influenced by the areas in which they have chosen to forage. For example, in order to optimize the efficiency of resource exploration and/or to occupy a desirable area, the ant species in question may create a polydomous nest or construct additions such as outstations (Debout et al. 2007; Lanan et al. 2011). According to the Debout (2007), polydomy has been observed in 166 species of 49 genera. In many cases, the change from monodomic to polydomic nesting occurred gradually, often as a consequence of exploration and foraging in areas undergoing continued change. This may well be the case here, given that "candeia" trees tend to thrive in altered environments and populations, in this study, presented with monospecific aggregates.

As the ant species studied occupied environments in which the vegetation presented little heterogeneity (and therefore fewer options for nesting), it is likely that they turned to occupying galls as a response to this difficulty, a response also observed by Cereto et al. (2011). Furthermore, Pfeiffer \& Linsenmair (1998) suggested that the polydomy in Camponotus gigas (Latreille, 1802) is related to habitat quality. According to them, polydomy in this case was a way of correcting the variation of habitat quality within the territory and of focusing the workers near the food source. Thus, we postulate that the occupation of the cavities resulting from the activity of herbivores in the canopy by ants can be important in maintaining populations of ants in monospecific patches with low heterogeneity of resources.

Longino (1987) suggests that despite the large number of specialized interactions between plant-life and ants, it is unlikely that the phenomenon of gall-occupation arose through any co-evolutive process. He points instead to competition as being a more likely possible factor. As shown by Silvestre et al. (2003) some species of Crematogaster are known to nest in vegetation and are considered dominant and territorial regarding food. This type of behavior can strongly influence the occupation and hierarchization of canopies. According to Palmer et al. (2008), in the African savanna, some species of Crematogaster play a key role in 
Table II. Ant species nesting in tree cavities formed by herbivorous endophytic insects (borers or galling insects) in the Brazilian cerrado.

\begin{tabular}{|c|c|c|c|}
\hline Species & Host plant & Cavity & Reference \\
\hline Azteca bicolor (Emery,1893) & Xylopia aromatica & Gall & Fernandes et al. (1988) \\
\hline Azteca bicolor (Emery,1893) & Xylopia aromatica & Gall & Craig et al. (1991) \\
\hline Azteca sp. & Xylopia aromatica & Gall & Fernandes et al. (1988) \\
\hline Brachymyrmex sp. & Vernonia polyanthes & Gall & Andrade et al. (1995) \\
\hline Brachymyrmex spp. & Xylopia aromatica & Gall & Craig et al. (1991) \\
\hline Brachymyrmex spp. & Xylopia aromatica & Gall & Craig et al. (1991) \\
\hline Camponotus sp. & Vernonia polyanthes & Gall & Andrade et al. (1995) \\
\hline Camponotus sp. & Diospyros hispida & Gall & Araújo et al. (1995) \\
\hline Camponotus sp. & Diospyros hispida & Gall & Araújo et al. (1995) \\
\hline Camponotus crassus (Mayr, 1862) & Xylopia aromatica & Gall & Craig et al. (1991) \\
\hline Cephalotes pusillus (Klug, 1824) & Unidentified species & Borer & Schoereder et al. (2010) \\
\hline Crematogaster brevispinosa (Mayr, 1870) & Diospyros hispida & Gall & Araújo et al. (1995) \\
\hline Crematogaster complex crinosa sp. 1 & Eremanthus erythropappus & Gall & This study \\
\hline Crematogaster complex crinosa sp. 2 & Eremanthus erythropappus & Gall & This study \\
\hline Crematogaster curvispinosa (Mayr, 1863) & Xylopia aromatica & Gall & Craig et al. (1991) \\
\hline Crematogaster goeldii (Forel, 1903) & Eremanthus erythropappus & Gall & This study \\
\hline Crematogaster sp. & Vernonia polyanthes & Gall & Andrade et al. (1995) \\
\hline lridomyrmex sp. & Vernonia polyanthes & Gall & Andrade et al. (1995) \\
\hline lridomyrmex spp. & Xylopia aromatica & Gall & Craig et al. (1991) \\
\hline lridomyrmex spp. & Xylopia aromatica & Gall & Craig et al. (1991) \\
\hline lridomyrmex spp. & Xylopia aromatica & Gall & Craig et al. (1991) \\
\hline Leptotorax sp. & Xylopia aromatica & Gall & Fernandes et al. (1988) \\
\hline Leptotorax sp. & Diospyros hispida & Gall & Araújo et al. (1995) \\
\hline Leptotorax wilda Smith, 1943 & Xylopia aromatica & Gall & Fernandes et al. (1988) \\
\hline Myrmelachista nodigera Mayr, 1887 & Xylopia aromatica & Gall & Craig et al. (1991) \\
\hline Myrmelachista nodigera Mayr, 1887 & Eremanthus erythropappus & Gall & This study \\
\hline Myrmelachista sp. & Vernonia polyanthes & Gall & Andrade et al. (1995) \\
\hline Myrmelachista sp. 1 & Eremanthus erythropappus & Gall & This study \\
\hline Myrmelachista spp. & Xylopia aromatica & Gall & Craig et al. (1991) \\
\hline Nesomyrmex aff. echinatinodis Forel, 1886 & Eremanthus erythropappus & Gall & This study \\
\hline Nesomyrmex spininodis (Mayr, 1887) & Eremanthus erythropappus & Gall & This study \\
\hline Pheidole sp. & Vernonia polyanthes & Gall & Andrade et al. (1995) \\
\hline Procryptocerus sp. 1 & Eremanthus erythropappus & Gall & This study \\
\hline Procryptocerus sp. 2 & Xylopia aromatica & Gall & Craig et al. (1991) \\
\hline Pseudomyrmex flavidus (Smith, 1858) & Xylopia aromatica & Gall & Craig et al. (1991) \\
\hline Pseudomyrmex flavidus (Smith, 1858) & Xylopia aromatica & Gall & Fernandes et al. (1988) \\
\hline Pseudomyrmex gracilis (Fabricius, 1804) & Diospyros hispida & Gall & Araújo et al. (1995) \\
\hline Pseudomyrmex sp. & Vernonia polyanthes & Gall & Andrade et al. (1995) \\
\hline Pseudomyrmex sp. & Xylopia aromatica & Gall & Craig et al. (1991) \\
\hline Pseudomyrmex sp. A & Xylopia aromatica & Gall & Fernandes et al. (1988) \\
\hline Pseudomyrmex sp. B & Xylopia aromatica & Gall & Fernandes et al. (1988) \\
\hline Pseudomyrmex subtilissimus (Emery, 1890) & Xylopia aromatica & Gall & Craig et al. (1991) \\
\hline Solenopsis sp. & Diospyros hispida & Gall & Araújo et al. (1995) \\
\hline Solenopsis sp. & Vernonia polyanthes & Gall & Andrade et al. (1995) \\
\hline Zacryptocerus pallens (Klug, 1824) & Xylopia aromatica & Gall & Fernandes et al. (1988) \\
\hline Zacryptocerus pavonii (Latreille, 1809) & Xylopia aromatica & Gall & Craig et al. (1991) \\
\hline Zacryptocerus pusillus (Klug, 1824) & Diospyros hispida & Gall & Araújo et al. (1995) \\
\hline Zacryptocerus pusillus (Klug, 1824) & Xylopia aromatica & Gall & Fernandes et al. (1988) \\
\hline Zacryptocerus pusillus (Klug, 1824) & Xylopia aromatica & Gall & Craig et al. (1991) \\
\hline Zacryptocerus sp. & Vernonia polyanthes & Gall & Andrade et al. (1995) \\
\hline Zacryptocerus sp. A & Xylopia aromatica & Gall & Fernandes et al. (1988) \\
\hline Zacryptocerus sp. B & Xylopia aromatica & Gall & Fernandes et al. (1988) \\
\hline Zacryptocerus spp. & Xylopia aromatica & Gall & Craig et al. (1991) \\
\hline
\end{tabular}


structuring the local arthropod community. Some may behave aggressively and significantly reduce the presence of other herbivores in the host plant (such as cerambycid borers), whereas other Crematogaster species may, on the contrary, not only tolerate the presence other insects (such as endophytics), but actively benefit from them, for example by appropriating of larvae-created cavities for nesting. Still other species may display behaviors such as cutting the axillary buds of their plants, killing the apical meristems of the canopy as a way to prevent invasion from neighboring ants. Furthermore, Carvalho \& Vasconcelos (2002) suggest that ant species known to create larger colonies, such as many species of the Crematogaster, may turn to creating polydomic nests as a way of dealing with space restrictions caused by twigs, which may play a part in explaining the results of this study as well.

Myrmelachista nodigera ants were the most abundant in our study, including in the median number of eggs per colony (Table I). They are a species of small-bodied ants native to the neotropics, specialized in foraging and nesting exclusively in vegetation (Silvestre et al. 2003; Longino 2006). Nakano et al. (2012) reported the occurrence of nests of this species in fallen twigs in the leaf litter. According to these authors, these twigs with nests possibly came from trees that have fallen due to winds and storms. However, Lanan et al. (2011) observed the genus Myrmelachista forming polidomic nests, and as suggested by Nakano et al. (2012), nests in cavities in fallen twigs leaf litter can serve as nests satellites favoring the expansion of the colony.

Our study determined that the galls most frequently chosen by ants for occupation were those larger in size and more rounded or globular in shape. This is similar to the findings of Fernandes et al. (1988) concerning the occupation by ants of beetle galls in trees of Xylopia aromatica (Lam.) Mart. (Annonaceae). These authors suggest that the ants' choice of habitat is subject to strong selective pressure, given that it impacts the fitness of the queen and that securing a safe, suitable location for nesting is crucial to the survival of the colony (Carvalho \& Vasconcelos 2002).

In the Espinhaço and Mantiqueira mountains, $E$. erythropappus trees and their galls are found along altitudinal quotas lower down on the cerrado sensu stricto and continuing upwards to reach higher altitudes, occupying rocky outcrops and degraded areas of rupestrian fields (Carneiro et al. 2009; Coelho et al. 2013). Senescent galls can therefore represent an important - and even decisive - factor affecting the local species-mosaic of arboreal ants.

Overall, our research leads us to conclude that in Brazilian "candeia" trees, induced-galls represent an abundant and widely distributed resource that is essential to maintaining the diversity of ants in the tree. The need for polydomic nests and outstations may explain the use of galls by ants, and for this reason, we plan to continue our research in a forthcoming study that will analyze the role of stem-galls in the structuring of communities, as well as their effects on neighboring herbivore insects.

\section{ACKNOWLEDGEMENTS}

We thank two anonymous reviewers for their comments on versions of the manuscript and Dr. Rodrigo M. Feitosa for ant identifications. Financial support was provided by the Universidade Federal de Ouro Preto (Programa de PósGraduação em Ecologia de Biomas Tropicais - UFOP) and by the authors themselves. The logistical support was provided by Instituto Estadual de Florestas de Minas Gerais (IEF). This study was carried out as partial fulfillment of the requirements for the M.Sc. degree of M.F.B. Almeida at Universidade Federal de Ouro Preto.

\section{REFERENCES}

Andrade, G.I., Silva, I.M., Fernandes, G.W. \& Scatena, V.L. 1995. Aspectos biológicos das galhas de Tomoplagia rudolphi (Diptera: Tephritidae) em Vernonia polyanthes (Astereaceae). Revista Brasileira de Biologia 55: 819-829.

Araújo, A.P.A., Carneiro, M.A.A. \& Fernandes, G.W. 2003. Efeitos do sexo, do vigor e do tamanho da planta hospedeira sobre a distribuição de insetos indutores de galhas em Baccharis pseudomyriocephala Teodoro (Asteraceae). Revista Brasileira de Entomologia 47: 483490

Araújo, L.M., Lara, A.C.F. \& Fernandes, G.W. 1995. Utilization of Apion sp. (Coleoptera Apionidae) galls by an ant community in southeastern Brazil. Tropical Zoology 8: 319-324.

Armbrecht, I., Ivette, P. \& Vandermeer, J. 2004. Enigmatic biodiversity correlations: ant diversity responds to diverse resources. Science 304: 284-286.

Borges, R.A., Carneiro, M.A. \& Viana, P. 2011. Altitudinal distribution and species richness of herbaceous plants in campos rupestres of the Southern Espinhaço Range, Minas Gerais, Brazil. Rodriguésia 62:139-152.

Brown, W.L.Jr. 2000. Diversity of ants, p. 45-79. In: Agosti, D., Majer, J.D., Alonso, L.E. \& Schultz, T.R. (eds.). Ants: Standard Methods for Measuring and Monitoring Biodiversity. Washington D.C., Smithsonian Institution Press, xix +280 p.

Campos, R.I., Lopes, C.T., Magalhães, W.C.S. \& Vasconcelos, H.L. 2008. Estratificação vertical de formigas em Cerrado strictu sensu no Parque Estadual da Serra de Caldas Novas, Goiás, Brasil. Iheringia Série Zoologia 98: 311-316.

Carneiro, M.A.A., Borges, R.A.X., Araújo, A.P.A. \& Fernandes, G.W. 2009. Insetos indutores de galhas na porção sul da Cadeia do Espinhaço, Minas Gerais, Brasil. Revista Brasileira de Entomologia 53: 570 592.

Carneiro, M.A.A., Coelho, M.S. \& Fernandes, G.W. 2014. Galls in Brazilian Mountains: New Reports and Perspectives, p. 273-293. In: Fernandes, G.W. \& Santos, J.C. (eds.) Neotropical Insect Galls London, Springer, vii+502 p.

Carvalho, K.S. \& Vasconcelos, H.L. 2002. Comunidade de formigas que nidificam em pequenos galhos da serrapilheira em floresta da Amazônia Central, Brasil. Revista Brasileira de Entomologia 46: 115121.

Cereto, C.E., Schmidt, G.O., Martins, A.G., Castellani, T.T. \& Lopes, B.C. 2011. Nesting of ants (Hymenoptera, Formicidae) in dead postreproductive plants of Actinocephalus polyanthus (Eriocaulaceae), a herb of coastal dunes in southern Brazil. Insectes Sociaux 58: 469471.

Coelho, M.S., Carneiro, M.A.A., Branco, C., Borges, R.A.X \& Fernandes, G.W. 2013. Gall-inducing insects from campos de altitude, Brazil. Biota Neotropica 13: 139-151.

Craig, T.P., Araújo L.M., Itami, J.K. \& Fernandes, G.W. 1991. Development of the insect community centered on a leaf bud gall formed by a weevil 
(Coleoptera: Curculionidae) on Xylopia aromatica (Annonaceae). Revista Brasileira de Entomologia 35: 311-317.

Debout, G., Schatz, B., Elias, M. \& McKey, D. 2007. Polydomy in ants: what we know, what we think we know, and what remains to be done. Biological Journal of the Linnean Society 90: 319-348.

Del-Claro, K. \& Torezan-Silingardi, H.M. 2009. Insect-plant interactions: new pathways to a better comprehension of ecological communities in neotropical savannas. Neotropical Entomology 38: 159-164.

Dreger-Jauffret, F. \& Shorthouse, J.D. 1992. Diversity of gall-inducing insects and their galls, p. 8-33. In: Shorthouse, J.D. \& Rohfritsch, O. (eds.). Biology of insect-induced galls, Oxford, Oxford University Press, $\mathrm{xi}+285 \mathrm{p}$.

Fernandes, G.W., Boecklen, W.J., Martins, R.P. \& Castro, A.G. 1988. Ants associated with a coleopterous leaf-bud gall on Xylopia aromatica (Annonaceae). Proceedings of the Entomological Society of Washington 91: 81-87.

Jones, C.G., Lawton, J.H. \& Shachak, M. 1994. Organisms as ecosystem engineers. Oikos 69: 373-386

Kempf, W.W. 1959. A synopsis of the New World species belonging to the Nesomyrmex-group of the ant genus Leptothorax Mayr (Hymenoptera: Formicidae). Studia Entomologica (n.s.) 2: 391-432.

Klimes, P., Idigel, C., Rimandai, M., Fayle, T.M., Janda, M., Weiblen, G.D. \& Novotny, V. 2012. Why are there more arboreal ant species in primary than in secondary tropical forest? Journal of Animal Ecology 81: 1103-1112.

Lanan, M.C., Dornhaus, A. \& Bronstein, J.L. 2011. The function of polydomy: the ant Crematogaster torosa preferentially forms new nests near food sources and fortifies outstations. Behavioral Ecology and Sociobiology 65: 959-968.

Longino, J.T. 1987. Ant in live oak galls in Texas. National Geographic Research 3: 125-127.

Longino, J.T. 2003. The Crematogaster of Costa Rica. Zootaxa 151: 1-150.

Longino, J.T. 2006. A taxonomic review of the genus Myrmelachista (Hymenoptera: Formicidae) in Costa Rica. Zootaxa 1141:1-54.

Maia, V.C. \& Fernandes, G.W. 2004. Insect galls from Serra de São José (Tiradentes, MG, Brazil). Brazilian Journal of Biology 64: 423-445.

Nakano, M.A., Feitosa, R.M., Moraes, C.O., Adriano, L.D.C., Hengles, E.P., Longui, E.L. \& Morini, M.S.C. 2012. Assembly of Myrmelachista Roger (Formicidae: Formicinae) in twigs fallen on the leaf litter of Brazilian Atlantic Forest. Journal of Natural History 46: 2103-2115.

Nakano, M.A., Miranda, V.F.O., Souza, D.R., Feitosa, R.M. \& Morini, M.S.C. 2013. Occurrence and natural history of Myrmelachista Roger
(Formicidae: Formicinae) in the Atlantic Forest of southeastern Brazil. Revista Chilena de Historia Natural 86: 169-179.

Oliveira, P.S. \& Freitas, A.V.L. 2004. Ant-plant-herbivore interactions in the neotropical cerrado savanna. Naturwissenschaften 91: 557-570.

Palmer, T.M., Stanton, M.L., Young, T.P., Goheen, J.R., Pringle, R.M. \& Karban, R. 2008. Breakdown of an ant-plant mutualism follows the loss of large herbivores from an African savanna. Science 319: 192-195.

Pedralli, G., Teixeira, M.C.B. \& Nunes, Y.R. 1997. Estudos sinecológicos sobre a candeia (Vanillosmopsis erythropappa Schult. BIP) na Estação Ecológica do Tripuí, Ouro Preto, MG. Revista Árvore 21: 301-306.

Pedralli, G., Teixeira, M.C.B., Freitas, V.L.O., Meyer, S.T. \& Nunes, Y.R.F. 2000. Florística e fitossociologia da Estação Ecológica do Tripuí, Ouro Preto, MG. Ciências e Agrotecnologia 24: 103-136.

Pfeiffer, M. \& Linsenmair, K.E. 1998. Polydomy and the organization of foraging in a colony of the Malaysian giant ant Camponotus gigas (Hym./Form.). Oecologia 117: 579-590.

R Core Team (2012). R: A language and environment for statistical computing. R Foundation for Statistical Computing, Vienna, Austria. http://www.R-project.org.

Ribas, C.R., Schoereder, J.H., Pic, M. \& Soares, S.M. 2003. Tree heterogeneity, resource availability, and larger scale processes regulating arboreal ant species richness. Austral Ecology 28: 305-314.

Santos, J.C., Almeida-Cortez, J.S. \& Fernandes, G.W. 2012. Gall-inducing insects from Atlantic Forest of Pernambuco, Northeastern Brazil. Biota Neotropica 12: 196-212.

Sanver, D. \& Hawkins, B.A. 2000. Galls as habitats: the inquiline communities of insect galls. Basic and Applied Ecology 1: 3-11.

Schoereder, J.H., Sobrinho, T.G., Madureira, M.S., Ribas, C.R. \& Oliveira, P.S. 2010. The arboreal ant community visiting extrafloral nectaries in the Neotropical cerrado savanna. Terrestrial Arthropod Reviews 3: $3-27$.

Schoonhoven, L.M., van Loon, J.J.A. \& Dicke, M. 2005. Insect-plant biology. Oxford, Oxford University Press, xvii+421 p.

Silvestre, R., Brandão, C.R.F. \& Silva, R.R. 2003. Grupos funcionales de hormigas: el caso de los gremios del cerrado, p. 113-148. In: Fernández, F. (ed.) Introducción a las hormigas de la región neotropical. Bogotá, Instituto de Investigación de Recursos Biológicos Alexander von Humboldt, xxvi +398 p.

Sprent, P. \& Smeeton, N.C. 2007. Applied Nonparametric Statistical Methods. 4th ed. Boca Raton, Chapman \& Hall/CRC, viii+530 p.

Wheeler, J. \& Longino, J.T. 1988. Arthropods in live oak galls in Texas. Entomological News 99: 25-29.
Received 14 April 2014; accepted 6 August 2014

Associate Editor: Rodrigo S. M. Feitosa 